\title{
BIM maturity model for higher education institutions
}

\author{
Modelo de maturidade BIM para instituições de ensino \\ superior
}

\begin{abstract}
Jeferson Spiering Böes
José de Paula Barros Neto

Mariana Monteiro Xavier de Lima

Abstrac

$\mathbf{T}$

he literature presents several BIM maturity models for projects, organizations and individuals. However, there is still a gap in models for Higher Education Institutions (HEIs). Consequently, there is an absence of studies that measure the BIM maturity of those institutions. Thus, the present study aims at (i) present a BIM maturity matrix model for HEIs; (ii) perform the measurement of BIM maturity in the HEIs in the state of Ceará, Brazil. The developed model is structured into three BIM fields (Policies, Processes and Technology), through 16 criteria and divided into five maturity levels. This research analyzed 26 courses in Civil Engineering as well as Architecture and Urbanism, in both public and private HEIs, therefore obtaining the Degree of Maturity, the Maturity Index, as well as the characteristics of BIM use. As a contribution, the study presents: (i) a theoretical contribution through the proposal of a BIM maturity model for HEIs, allowing other institutions to measure their performance; (ii) BIM characterization in HEIs, as well as the barriers for its adoption, uses and BIM disciplines; (iii) measurement of HEIs' maturity. The measurement of BIM maturity in the HEIs in Ceará state allowed an overview of them, becoming part of a macro-diagnostic state in the sector.

Keywords: BIM maturity. Higher education institution. BIM adoption. Civil engineering. Architecture and Urbanism.

\section{Resumo}

A literatura apresenta diversos modelos de maturidade BIM para projetos, organizações e indivíduos, havendo uma lacuna de modelos destinados às Instituições de Ensino Superior. Consequentemente, vislumbra-se a ausência de trabalhos que mensuram a maturidade BIM das instituições. Desta forma, o presente estudo tem por objetivo (i) apresentar um modelo de matriz de

1Jeferson Spiering Böes ${ }^{1}$ Faculdade Ari de Sá Fortaleza - CE - Brasil

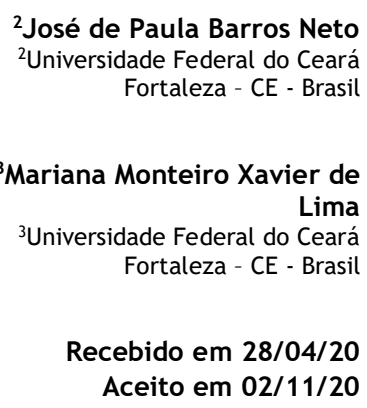

Recebido em 28/04/20

Aceito em 02/11/20 maturidade BIM para IES; (ii) realizar a mensuração da maturidade BIM nas IES do estado do Ceará. O modelo desenvolvido está estruturado em três campos BIM (Políticas, Processos e Tecnologia), através de 16 critérios e divididos em cinco níveis de maturidade. A pesquisa analisou 26 cursos de Engenharia Civil e Arquitetura e Urbanismo, em IES públicas e privadas, obtendo o Grau de Maturidade, o Índice de Maturidade e as características de utilização do BIM. Como contribuição, o estudo apresenta: (i) uma contribuição teórica, através da proposição de um modelo de maturidade BIM para as IES, permitindo que outras instituições possam mensurar seu desempenho; (ii) caracterização do BIM nas IES, as barreiras para adoção, usos e disciplinas BIM; (iii) mensuração da maturidade das IES. A mensuração da maturidade BIM nas IES do estado do Ceará permitiu um panorama das IES, fazendo parte de uma etapa de macrodiagnóstico do setor.

Palavras-chave: Maturidade BIM. Ensino de BIM. Adoção BIM. Engenharia Civil. Arquitetura e Urbanismo.
\end{abstract}




\section{Introduction}

Building Information Modeling (BIM) is considered one of the most promising developments in the Architecture, Engineering, Construction and Operation (AECO) sectors (AZHAR, 2011). The information model has become a well-established instrument and an innovative methodology to improve productivity throughout the life cycle of projects (ZHOU et al., 2017), and therefore should be seen as something that goes beyond a model of visualization of the projected space (TSE; WONG; WONG, 2005; CHEN; LUO, 2014).

The AECO industry interest in the adoption of BIM has increased, consequently elevating the demand for professionals with mastery of the tools and methodologies associated with it. However, there is a lack of trained professionals who are acknowledged with the benefits of information modeling processes (GODOY; CARDOSO; BORGES, 2013; LINO; AZENHA; LOURENÇO, 2012). In Brazil, the adoption of BIM is at an early stage in the training of professionals, whether at a technological, undergraduate or graduate level (ITO; SCHEER, 2017). Its adoption at the university level has been gradual and not very effective in Architecture and Civil Engineering courses (RUSCHEL; ANDRADE; MORAIS, 2013).

The Construction Information Modeling teaching approach must go beyond the instrumental training of the disciplines of applied computing. Therefore, with the increasing dissemination of BIM, Brazilian researchers have increased their concern with the inclusion of teaching it in Architecture and Civil Engineering courses (RUSCHEL; ANDRADE; MORAIS, 2013). The academic dissemination of BIM in Brazil has been a relevant growth driver in the last decade (MACHADO; RUSCHEL; SCHEER, 2017). It is up to universities to train the new professionals who will implement BIM in AECO (RUSCHEL; ANDRADE; MORAIS, 2013).

The present study is part of a group of research carried out, initiated in 2018 (BÖES; LIMA; BARROS NETO, 2018), which aims at carrying out the BIM implementation in Ceará state through a macro approach involving the various sector stakeholders (BÖES, 2019). Therefore, this study aims at presenting a theoretical model of BIM maturity matrix for Higher Education Institutions (HEIs) and applying it in the courses of Architecture and Urbanism and Civil Engineering in Ceará state, identifying the maturity of the HEIs in the state.

\section{Teaching BIM}

In order to prepare future professionals to meet the growing demand of organizations in the use of BIM processes and methodologies, it is necessary to include their concepts in the undergraduate curricula of Architecture and Civil Engineering (AEC), (BASTO; LORDSLEEM JUNIOR, 2016).

BIM teaching approach must go beyond the instrumental training present in the disciplines of applied computing (RUSCHEL; ANDRADE; MORAIS, 2013; LEAL; SALGADO, 2019), and its adoption should be planned and advance in stages of maturity (SUCCAR, 2009; JERNIGAN, 2007; COMPUTER..., 2011; JUNG; JOO, 2011; GU; LONDON, 2010).

Some barriers stand out in the process of BIM adoption at universities, such as: new teaching methodologies; material, books and other specific sources deficiency; difficulty in finding BIM acknowledged teachers; platform costs; the required multidisciplinarity, development of curricular components, and lack of rules and requirements for the curriculum implementation (SABONGI, 2009; SACKS; PIKAS, 2013; CHECCUCCI, 2014). However, despite these barriers, studies present outstanding experiences abroad (GORDON; AZAMBUJA; WERNER, 2009; SACKS; BARAK, 2010; CLEVENGER et al., 2010; WONG; WONG; NADEEM, 2009; PETERSON et al., 2011; BECERIK-GERBER; KU; JAZIZADEH, 2012).

A positive perspective for BIM adoption in the Brazil was the publication of the Federal Decree 9.337: 2018 (CHECCUCCI, 2019), that was later replaced by the Federal Decree 9.983: 2019, which institutes BIM's National Dissemination Strategy, presenting its purpose, objectives, actions, indicators and goals (BRASIL, 2018, 2019). Among its nine specific objectives, we can highlight three that have a relationship and (are the) responsibility of Higher Education Institutions, as shown in Table 1. More recently, still within the scope of the National Strategy, the Federal Government published the Federal Decree 10.306 (BRASIL, 2020) that establishes the BIM use in the direct or indirect execution of engineering projects and services performed by the agencies and entities of the federal administration (BRASIL, 2020).

132 Böes, J. S.; Barros Neto, J. De P.; Lima, M. M. X. de 
Table 1 - Objectives and Actions of the BIM BR Strategy directly related to HEls

\begin{tabular}{|l|l|l|}
\hline \multicolumn{1}{|c|}{ Specific Objectives } & \multicolumn{1}{|c|}{ Strategic Actions } & Relation \\
\hline \multirow{3}{*}{$\begin{array}{l}\text { Stimulate capacity in } \\
\text { BIM }\end{array}$} & $\begin{array}{l}\text { I. Establish learning objectives and BIM skills for each level of } \\
\text { performance in order to guide the offer of courses; } \\
\text { II. Train administrators and civil servants in BIM; } \\
\text { III. Encourage a greater insertion of BIM in Engineering and } \\
\text { Architecture undergraduate and graduate-level courses; } \\
\text { IV. Stimulate the professional BIM certification. }\end{array}$ & Direct \\
\hline $\begin{array}{l}\text { Stimulate the } \\
\text { development and } \\
\text { application of new } \\
\text { technologies related to } \\
\text { BIM }\end{array}$ & $\begin{array}{l}\text { I. Encourage investments in BIM labs in scientific, technological } \\
\text { andinnovation Institutions; } \\
\text { II. Adapt research, development and innovation programs to the } \\
\text { promotion needs of BIM (eg. CNPQ, FINEP, among others). }\end{array}$ & Indirect \\
\hline \multirow{2}{*}{$\begin{array}{l}\text { Disseminate BIM and } \\
\text { its benefits }\end{array}$} & $\begin{array}{l}\text { I. Implement a communication plan to disseminate the } \\
\text { objectives and actions of the BIM BR Strategy; } \\
\text { II. Implement a communication plan mainly through } \\
\text { publications, events and the use of digital media to make public } \\
\text { the BIM concept, its benefits, good practices and successful } \\
\text { stories; } \\
\text { III. Raise awareness on the actors about the importance of BIM } \\
\text { adoption and the need for structural changes for its proper } \\
\text { implementation; } \\
\text { IV. Decrease regional inequalities regarding the dissemination } \\
\text { of BIM through actions to raise awareness among local actors; } \\
\text { V. Disseminate instruments to support BIM use (eg. BIM guides } \\
\text { and BIM Platform). }\end{array}$ & Indirect \\
\hline
\end{tabular}

Source: adapted from Brazil (2018).

The strategies for BIM adoption in the teaching of AEC can occur through two approaches:

(a) the creation of new disciplines with specific content in BIM; or

(b) the introduction of BIM in several existing disciplines as a resource to help the BIM assimilation (BARISON; SANTOS, 2011; ANDRADE, 2018).

Ruschel, Andrade and Morais (2013) propose a BIM classification in stages of implementation and their respective competence levels. At the first level, the emphasis is on parametric modeling; while the second level aims at multidisciplinarity and the third level aims at collaboration.

In Brazil, the National Meeting on BIM Teaching (ENEBIM) emerged in 2018, with the objective of bringing together didactic experiences and promoting discussion, uniting the scientific community, teachers, instructors and specialists around BIM teaching and learning (SALGADO, 2019). On ENEBIM two editions, 92 studies were presented, with emphasis on the states of Ceará ( 24 studies), Rio Grande do Norte and São Paulo (12 studies each). Among the universities that shared their experiences the ones that led the publications were:

(a) Universidade Federal do Ceará (10 studies);

(b) Faculdade Ari de Sá (9 studies);

(c) Instituto Federal do Rio Grande do Norte (5 studies);

(d) Universidade Federal do Rio Grande do Sul; and

(e) Universidade Estadual de Campinas (4 studies each).

In an analysis of the classification of the implementation stages proposed by Ruschel, Andrade and Morais (2013) about the experiences shared at ENEBIM, it can be noticed that $9 \%$ are in the third stage (collaboration), $15 \%$ are in the second stage (multidisciplinarity) and $76 \%$ are in the first stage, parametric modeling. These data indicate that there is still a lot of room for improvement, especially in the multidisciplinarity and collaboration stages. 


\section{BIM maturity}

The concept of BIM maturity is used to identify a set of process improvements that enable the achievement of specific benefits (SUCCAR, 2009), providing a better understanding of the growth and diversity of BIM's application (SEBASTIAN; BERLO, 2010).

BIM capacity can be defined as the ability to generate deliverables and services, whereas BIM maturity can be understood as the extent, depth, quality, predictability and replicability of this ability when performing a task or delivering a Bim service or product (SUCCAR, 2009). BIM maturity indicates the level of progress in the use of BIM (JUNG; JOO, 2011). The BIM Maturity Matrix (BIm ) developed by Succar (2010), proposes that the maturity of an organization must be supported through three BIM fields: technology, processes and policies, in which each field will present its own stakeholders, requirements and deliverables . Table 2 shows the BIM fields.

Maturity models should contribute to highlight the different stages of BIM development in the fields of technology, processes and protocols and not only contribute to the measurement of the general maturity index (LIANG et al., 2016).

Several studies (WU et al., 2017) and maturity matrix models have been developed (NATIONAL..., 2007; BEW; RICHARDS, 2008; INDIANA..., 2009; BIMSCORE, 2009; SEBASTIAN; BERLO, 2010; SUCCAR, 2010; VICO, 2011; CONSTRUCTION..., 2011; COMPUTER..., 2011; SUCCAR; KASSEM, 2015; GIEL; ISSA, 2013; LIANG et al., 2016), covering two main categories: those that evaluate the maturity of individual projects and those that evaluate the maturity of organizations that are implementing the process (GIEL; ISSA, 2013), as shown in Table 3. The models focus on organizations, mostly building companies, designers or managers, or individuals, leaving a gap of instruments that measure the BIM maturity of HEIs.

\section{Methodology}

The present study adopts the Design Science Research (DSR) as its research strategy, proposing, at the end, an artifact: the HEIs BIM maturity matrix, bridging the existing gap in the literature (HEVNER, 2007; LUKKA, 2003; VAN AKEN, 2004; HOLMSTRON; KETOKIVI; HAMERI, 2009).

The design of this research is based on the constructive research process (HOLMSTRON; KETOKIVI; HAMERI, 2009), proposing three phases:

(a) Understanding;

(b) Development of a Solution; and

(c) Analysis and Reflection.

Table 2 - BIM Maturity Matrix (BIm³) Fields

\begin{tabular}{|c|l|}
\hline Field & \multicolumn{1}{c|}{ Description } \\
\hline Technology & $\begin{array}{l}\text { The Technology Field gathers a group of actors specialized in the development of } \\
\text { software, hardware, equipment and network systems necessary to increase the } \\
\text { efficiency, productivity and profitability of AECO sectors. These include organizations } \\
\text { that generate software and equipment solutions with direct and indirect applicability to } \\
\text { the facilities design, construction and operation. }\end{array}$ \\
\hline Process & $\begin{array}{l}\text { The Process Field gathers a group of actors who acquire, design, build, manufacture, } \\
\text { use, manage and maintain structures. These include facility owners, architects, } \\
\text { engineers, contractors, facility managers and all other AECO industry participants } \\
\text { involved in the ownership, delivery and operations of buildings or structures. }\end{array}$ \\
\hline Policies & $\begin{array}{l}\text { The Policy Field gathers a group of actors with a focus on training professionals, } \\
\text { research, benefit distribution, risk allocation and conflict reduction within the AECO } \\
\text { industry. These actors do not generate any construction products, but are specialized } \\
\text { organizations, such as insurance companies, research centers, educational institutions } \\
\text { and regulatory bodies, that play a fundamental role in the preparation, regulation and } \\
\text { contract in the process of design, construction and operation. }\end{array}$ \\
\hline
\end{tabular}

Source: Succar (2010). 
Table 3 - Comparison among BIM Maturity Models

\begin{tabular}{|c|c|c|c|c|c|}
\hline Model & Reference & Topics & Sublevels & $\begin{array}{c}\text { Maturity } \\
\text { Levels }\end{array}$ & $\begin{array}{c}\text { Target } \\
\text { Audience } \\
\end{array}$ \\
\hline$I-C M M$ & NIBS (NATIONAL..., 2007) & 11 & - & 10 & Organizations \\
\hline $\begin{array}{l}\text { BIM Proficiency } \\
\text { Matrix }\end{array}$ & Indiana University (2009) & 8 & - & 5 & Organizations \\
\hline $\begin{array}{l}\text { BIM Maturity Levels } \\
\text { (iBIM) }\end{array}$ & Bew and Richards (2008) & - & - & 4 & Organizations \\
\hline BIM QuickScan & Sebastian and Berlo (2010) & 4 & 50 & - & Organizations \\
\hline Vico BIM score & VICO (2011) & 3 & 4 & Score & Managers \\
\hline $\begin{array}{c}\text { CPIx-BIM } \\
\text { Assessment Form }\end{array}$ & $\begin{array}{c}\text { CPI (CONSTRUCTION..., } \\
\text { 2011) }\end{array}$ & 4 & 12 & - & Projects \\
\hline bimSCORE & bimSCORE (2009) & 4 & 50 & Score & VDC \\
\hline $\begin{array}{c}\text { The Organizational } \\
\text { BIM Assessment } \\
\text { Profile }\end{array}$ & $\begin{array}{l}\text { Cmputer Integrated } \\
\text { Construction Research } \\
\text { Programm (2011) }\end{array}$ & 6 & 20 & 5 & Organizations \\
\hline $\begin{array}{c}\text { BIM Competency } \\
\text { Assessment Tool } \\
(\text { BIMCAT })\end{array}$ & Giel and Issa (2013) & 12 & 66 & Score & Owners \\
\hline $\begin{array}{l}\text { Multifunctional BIM } \\
\text { Maturity Model }\end{array}$ & Liang et al. (2016) & 3 & 21 & 4 & Organizations \\
\hline $\begin{array}{l}\text { BIM Maturity Matrix } \\
\left(\text { BIM }^{3}\right)\end{array}$ & Succar (2010) & 5 & 16 & 5 & Organizations \\
\hline $\begin{array}{c}\text { Macro Maturity } \\
\text { Matrix }\end{array}$ & Succar and Kassem (2015) & 8 & - & 5 & Chain \\
\hline
\end{tabular}

Source: adapted from Wu et al. (2017).

To go with the phases, the work was divided into seven stages:

(a) analysis of the existing maturity models;

(b) theoretical development of m BIM (IES);

(c) sample definition;

(d) development of the research instrument to collect information;

(e) research instrument testing;

(f) research instrument application; and

(g) results analysis and reflection.

\section{Theoretical development of $\mathrm{m}^{2} \mathrm{BIM}$-HEls}

The BIM Maturity Matrix for HEIs (m BIM-HEIs) was developed based on the matrices developed by NIBS (NATIONAL..., 2007), Bew and Richards (2008), IU (INDIANA..., 2009), Succar, 2010), bimSCORE (2009), CIFE (CENTER..., 2013 ) and CIC (COMPUTER..., 2011), as well as in the studies developed by Sabongi (2009), Sacks and Pikas (2013), Ruschel, Andrade and Morais (2013), Checcucci (2014), Machado, Ruschel and Scheer (2017) and Checcucci (2019). The matrix presentation will be covered in the results section.

\section{Sample}

In order to define the HEIs for applying the maturity model in this research, the adopted criterion was choosing HEIs that are accredited with the Ministry of Education (MEC), through the e-mec website. The sample was limited to in-person courses taught in the state of Ceará, and to the degrees of Architecture and Urbanism and Civil Engineering. 
The questionnaire was intended for Course Coordinators and Center Administrators, as a way to obtain an institutional response of the course. Despite obtaining an institutional view, the results are based on information resulting from the respondents' self-declarations, without going through any audit process.

In total, the research gathered a sample of 26 undergraduate courses, being 17 courses of Civil Engineering, and 9 courses of Architecture and Urbanism, from all regions of the state, both public and private institutions, being 5 public and 21 private undergraduate courses, as shown in Figure 1. The study included undergraduate courses located in the cities of Fortaleza (16 courses), Juazeiro do Norte (3 courses), Sobral (3 courses), Quixadá (2 courses), Crateús and Russas (both with 1 course).

\section{Research tool, test and application}

A research instrument was developed for the application of $\mathrm{m}$ BIM-HEI. It was a structured questionnaire which was applied online. The decision about this research instrument was due to the size and geographic range of the sample, making in-person interviews unfeasible. The questionnaire aimed at creating a mechanism to apply m BIM-HEI through guided questions. It was composed of open and closed-ended questions and it was organized into 5 sections:

(a) introduction;

(b) there is no contact with BIM;

(c) BIM initiatives;

(d) faculty training; and

(e) technology.

The instrument was developed and applied through an online platform, and it was sent to the respondents' institutional emails.

After the first version of the research instrument was completed, a pre-test was applied simultaneously to three HEIs, as a way to test the instrument and validate it. After this stage, the instrument was updated and forwarded to the HEIs.

Figure 1 - HEls characterization
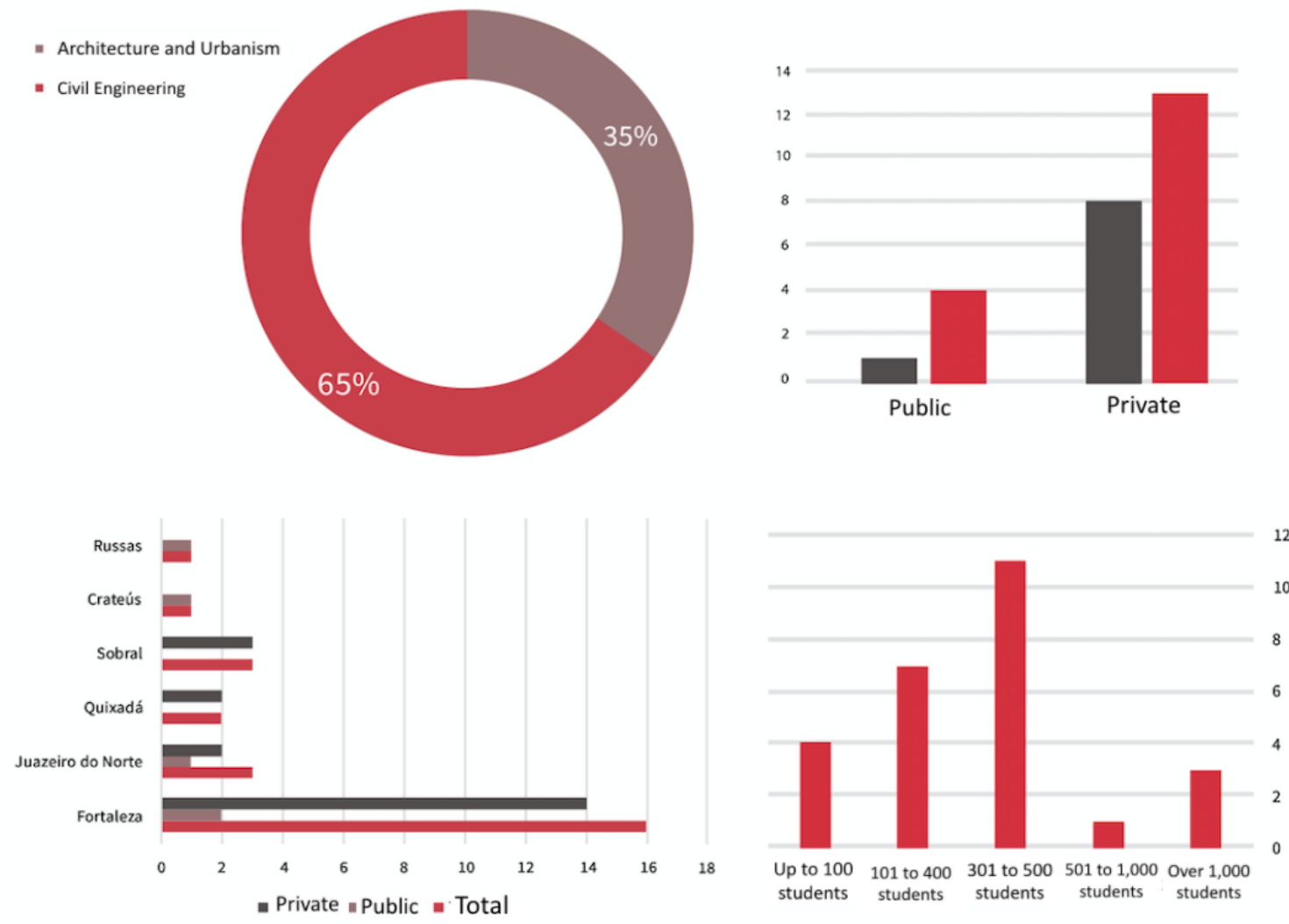

136 Böes, J. S.; Barros Neto, J. De P.; Lima, M. M. X. de 


\section{Results}

\section{BIM Maturity Matrix for HEls ( $\left.m^{2} \mathrm{BIM}-\mathrm{HEI}\right)$}

The BIM Maturity Matrix for HEIs (m BIM-HEI) is an artifact, an intended tool exclusively for Higher Education Institutions. Its focus may be on the institution or on the course itself. It can be applied by the members of the institution as an internal knowledge tool in order to measure performance, as well as it can be used for measurements by external agents.

The m BIM-HEI is divided into three BIM fields: Policy, Processes and Technology (SUCCAR; 2010), presented and conceptualized in Table 4. In each BIM field there is a set of criteria (NATIONAL..., 2007; INDIANA..., 2009; BEW; RICHARDS , 2008; BIMSCORE, 2009; CENTER..., 2013; COMPUTER..., 2011; SUCCAR, 2010; CHECCUCCI, 2014; SACKS; PIKAS, 2013; SABONGI, 2009; RUSCHEL; ANDRADE; MORAIS, 2013; MACHADO; RUSCHEL; SCHEER, 2017; CHECCUCCI, 2019; BARISON; SANTOS, 2011), totaling 16 criteria.

The theoretical model of $\mathrm{m}$ BIM-HEI, illustrated in Tables 5, 6 and 7, presents the maturity on a progressive scale of five levels:

(a) pre-BIM;

(b) initial;

(c) defined;

(d) integrated; and

(e) optimized (SUCCAR; 2010).

The advance in maturity levels is related to the gradual, continuous improvements and to the formalization and institutionalization of BIM within the HEI. The Pre-BIM level is the absence of BIM in the HEI, while the Optimized level consists of the highest maturity level.

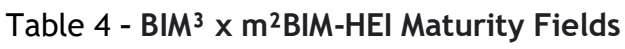

\begin{tabular}{|c|l|l|}
\hline Field & \multicolumn{1}{|c|}{ BIM $^{\mathbf{3}}$ (SUCCAR, 2010) } & \multicolumn{1}{c|}{ mBIM-HEI $^{2}$ BIM } \\
\hline Policy & $\begin{array}{l}\text { The Policy Field gathers a group } \\
\text { of actors with a focus on training } \\
\text { professionals, research, benefit } \\
\text { distribution, risk allocation and } \\
\text { conflict reduction within the } \\
\text { AECO industry. }\end{array}$ & $\begin{array}{l}\text { The Policy Field comprises all initiatives, actions } \\
\text { and institutional view about BIM. It encompasses } \\
\text { the training of the faculty staff, the faculty staff } \\
\text { BIM engagement, the BIM institutional vision, the } \\
\text { actions of BIM teaching, academic extension, } \\
\text { scientific initiation and the federal decree 9.337: } \\
\text { 2018. }\end{array}$ \\
\hline \multirow{5}{*}{ Process } & $\begin{array}{l}\text { The Process Field gathers a group } \\
\text { of actors who acquire, design, } \\
\text { build, manufacture, use, manage } \\
\text { and maintain structures. }\end{array}$ & $\begin{array}{l}\text { The Process Field comprises the uses of BIM, the } \\
\text { form and number of disciplines in which BIM is } \\
\text { involved, the forms, quality and quantity of } \\
\text { publications of scientific articles and the scope of } \\
\text { trained students. }\end{array}$ \\
\hline Technology & $\begin{array}{l}\text { The Technology Field gathers a } \\
\text { group of actors specialized in the } \\
\text { development of software, } \\
\text { hardware, equipment and network } \\
\text { systems necessary to increase the } \\
\text { efficiency, productivity and } \\
\text { profitability of AECO sectors. }\end{array}$ & $\begin{array}{l}\text { The Technology Field comprises all infrastructure } \\
\text { for the development of teaching, research and BIM } \\
\text { extension in Higher Education Institutions, whether } \\
\text { by technological or physical means. It is related to } \\
\text { institutional agreements with software developers } \\
\text { and hardware manufacturers, the types and uses of } \\
\text { software and hardware, in addition to the physical } \\
\text { infrastructure of the BIM learning spaces. }\end{array}$ \\
\hline
\end{tabular}


Table 5 - m²BIM-HEl (Policy Field)

\begin{tabular}{|c|c|c|c|c|c|}
\hline NM & $\begin{array}{c}\text { Pre-BIM } \\
5 \mathrm{pts} \\
\end{array}$ & $\begin{array}{l}\text { Initial } \\
20 \mathrm{pts}\end{array}$ & $\begin{array}{c}\text { Defined } \\
30 \mathrm{pts}\end{array}$ & $\begin{array}{c}\text { Integrated } \\
40 \mathrm{pts} \\
\end{array}$ & $\begin{array}{c}\text { Optimized } \\
50 \mathrm{pts}\end{array}$ \\
\hline \multicolumn{6}{|c|}{ Policy } \\
\hline $\begin{array}{c}\text { Faculty Bim } \\
\text { Engagement } \\
\text { (P.2) }\end{array}$ & $\begin{array}{l}\text { The faculty } \\
\text { has no BIM } \\
\text { knowledge } \\
\text { and there is no } \\
\text { engagement. }\end{array}$ & $\begin{array}{l}\text { Up to } 10 \% \text { of the } \\
\text { faculty knows the } \\
\text { BIM methodology } \\
\text { and software. } \\
\text { There is no kind of } \\
\text { engagement. }\end{array}$ & $\begin{array}{l}\text { Up to } 10 \% \text { of the } \\
\text { faculty knows the } \\
\text { BIM methodology } \\
\text { and software. } \\
\text { There is a preliminary } \\
\text { engagement of the } \\
\text { faculty. }\end{array}$ & $\begin{array}{l}\text { Up to } 30 \% \text { of the } \\
\text { faculty knows the } \\
\text { BIM methodology } \\
\text { and software. } \\
\text { There is faculty } \\
\text { engagement (study } \\
\text { group, scientific } \\
\text { initiation, academic } \\
\text { extension, BIM } \\
\text { inclusion in } \\
\text { disciplines, etc.). }\end{array}$ & $\begin{array}{l}\text { Over } 30 \% \text { of the faculty knows } \\
\text { the BIM methodology and } \\
\text { software. } \\
\text { There is faculty engagement } \\
\text { (study group, scientific } \\
\text { initiation, academic extension, } \\
\text { BIM inclusion in disciplines, } \\
\text { etc.). }\end{array}$ \\
\hline $\begin{array}{c}\text { BIM } \\
\text { Institutional } \\
\text { View } \\
\text { (P.3) }\end{array}$ & $\begin{array}{l}\text { BIM is not } \\
\text { viewed as } \\
\text { important, a } \\
\text { priority or as a } \\
\text { methodology } \\
\text { in the } \\
\text { teaching- } \\
\text { learn- } \\
\text { ing process } \\
\text { for students. }\end{array}$ & $\begin{array}{l}\text { BIM is not viewed as } \\
\text { important, a priority } \\
\text { or as a teaching-learn- } \\
\text { ing process } \\
\text { methodology for } \\
\text { students. However, } \\
\text { there is no internal } \\
\text { barrier for professors' } \\
\text { initiatives. }\end{array}$ & $\begin{array}{l}\text { BIM is viewed as } \\
\text { important, but not as } \\
\text { a priority or as a } \\
\text { teaching-learning } \\
\text { process methodology } \\
\text { for students. }\end{array}$ & $\begin{array}{l}\text { BIM is viewed as a } \\
\text { priority by the HEI } \\
\text { and a means for the } \\
\text { teaching-learning } \\
\text { process. However, } \\
\text { there is no } \\
\text { formalization of } \\
\text { this institutional } \\
\text { view. }\end{array}$ & $\begin{array}{l}\text { BIM is viewed as a priority by } \\
\text { the HEI and a means for the } \\
\text { teaching-learning process. It is } \\
\text { inserted in the Course } \\
\text { Pedagogical Project and in the } \\
\text { disciplines Syllabi. }\end{array}$ \\
\hline $\begin{array}{c}\text { Academic } \\
\text { Extension } \\
\quad(P .5)\end{array}$ & $\begin{array}{l}\text { There is no } \\
\text { BIM initiative } \\
\text { in the } \\
\text { academic } \\
\text { extension. }\end{array}$ & $\begin{array}{l}\text { There is no formal } \\
\text { BIM initiative in the } \\
\text { academic extension. } \\
\text { There are faculty or } \\
\text { students' individual } \\
\text { initiatives without the } \\
\text { formalized knowledge } \\
\text { of the HEI. }\end{array}$ & $\begin{array}{l}\text { There is no formal } \\
\text { BIM initiative in the } \\
\text { academic extension. } \\
\text { There are faculty or } \\
\text { students' individual } \\
\text { initiatives with the } \\
\text { formalized } \\
\text { knowledge of the } \\
\text { HEI. }\end{array}$ & $\begin{array}{l}\text { There are } \\
\text { institutionalized } \\
\text { and formalized } \\
\text { BIM initiatives in } \\
\text { the academic } \\
\text { extension. } \\
\text { The initiatives are } \\
\text { not related to BIM } \\
\text { strategic planning. }\end{array}$ & $\begin{array}{l}\text { There are institutionalized and } \\
\text { formalized BIM initiatives in } \\
\text { the academic extension. } \\
\text { The set of actions (courses, } \\
\text { lectures, seminars, etc.) } \\
\text { converge to the BIM strategic } \\
\text { planning. }\end{array}$ \\
\hline $\begin{array}{l}\text { Scientific } \\
\text { Initiation } \\
\quad(P .6)\end{array}$ & $\begin{array}{l}\text { There is no } \\
\text { BIM initiative } \\
\text { in the } \\
\text { Scientific } \\
\text { Initiation. }\end{array}$ & $\begin{array}{l}\text { There is no BIM } \\
\text { initiative in the } \\
\text { Scientific Initiation. } \\
\text { However, there are } \\
\text { study groups aiming } \\
\text { at creating a BIM } \\
\text { scientific initiation. }\end{array}$ & $\begin{array}{l}\text { There is no } \\
\text { formalized Scientific } \\
\text { Initiation, there are } \\
\text { only individual } \\
\text { actions among the } \\
\text { faculty staff and } \\
\text { students in the } \\
\text { research production. }\end{array}$ & $\begin{array}{l}\text { There are } \\
\text { formalized BIM } \\
\text { Scientific Initiation } \\
\text { initiatives, with } \\
\text { lines of research } \\
\text { consolidated in the } \\
\text { HEI. }\end{array}$ & $\begin{array}{l}\text { There are formalized BIM } \\
\text { Scientific Initiation initiatives, } \\
\text { with lines of research } \\
\text { consolidated in the HEI. } \\
\text { BIM is viewed as a priority at } \\
\text { the Scientific Initiation. }\end{array}$ \\
\hline $\begin{array}{c}\text { Federal } \\
\text { Decree 9.337 } \\
\text { (BRASIL, } \\
\text { 2018) } \\
\text { (P.7) }\end{array}$ & $\begin{array}{l}\text { There is no } \\
\text { knowledge } \\
\text { about its } \\
\text { content. }\end{array}$ & $\begin{array}{l}\text { The HEI has } \\
\text { knowledge about its } \\
\text { content. } \\
\text { There is no } \\
\text { plan/strategy to meet } \\
\text { the requirements and } \\
\text { it has not been } \\
\text { developing any } \\
\text { action. }\end{array}$ & $\begin{array}{l}\text { The HEI has } \\
\text { knowledge about its } \\
\text { content. } \\
\text { There is no } \\
\text { plan/strategy to meet } \\
\text { the requirements but } \\
\text { it has been } \\
\text { developing an action. }\end{array}$ & $\begin{array}{l}\text { The HEI has } \\
\text { knowledge about } \\
\text { its content. } \\
\text { There is an } \\
\text { established } \\
\text { plan/strategy to } \\
\text { meet its } \\
\text { requirements. }\end{array}$ & $\begin{array}{l}\text { The HEI has knowledge about } \\
\text { its content. } \\
\text { There is an established } \\
\text { plan/strategy to meet its } \\
\text { requirements. } \\
\text { The HEI has the commitment } \\
\text { to meet the decree criteria. }\end{array}$ \\
\hline
\end{tabular}


Table 6 - m²BIM-HEI (Process Field)

\begin{tabular}{|c|c|c|c|c|c|}
\hline NM & $\begin{array}{c}\text { Pre-BIM } \\
5 \mathrm{pts}\end{array}$ & $\begin{array}{l}\text { Initial } \\
20 \mathrm{pts}\end{array}$ & $\begin{array}{c}\text { Defined } \\
30 \text { pts }\end{array}$ & $\begin{array}{c}\text { Integrated } \\
40 \mathrm{pts}\end{array}$ & $\begin{array}{l}\text { Optimized } \\
50 \mathrm{pts}\end{array}$ \\
\hline \multicolumn{6}{|c|}{ Process } \\
\hline $\begin{array}{l}\text { BIM Use } \\
\text { (R.1) }\end{array}$ & $\begin{array}{l}\text { There is no } \\
\text { BIM use. }\end{array}$ & $\begin{array}{l}\text { Up to } 5 \text { BIM } \\
\text { uses. }\end{array}$ & $\begin{array}{l}\text { Up to } 10 \text { BIM } \\
\text { uses. }\end{array}$ & $\begin{array}{l}\text { Up to } 15 \text { BIM } \\
\text { uses. }\end{array}$ & $\begin{array}{l}\text { Over } 15 \text { BIM } \\
\text { uses. }\end{array}$ \\
\hline $\begin{array}{c}\text { BIM } \\
\text { Disciplines } \\
\text { (R.2) }\end{array}$ & $\begin{array}{l}\text { There is no } \\
\text { discipline that } \\
\text { encompasses } \\
\text { BIM. }\end{array}$ & $\begin{array}{l}\text { There is } 1 \\
\text { discipline that } \\
\text { encompasses } \\
\text { BIM. }\end{array}$ & $\begin{array}{l}\text { There are up to } \\
5 \text { disciplines } \\
\text { that encompass } \\
\text { BIM. }\end{array}$ & $\begin{array}{l}\text { There are up to } \\
15 \text { disciplines } \\
\text { that encompass } \\
\text { BIM. }\end{array}$ & $\begin{array}{l}\text { There are over } \\
15 \text { disciplines } \\
\text { that encompass } \\
\text { BIM. }\end{array}$ \\
\hline $\begin{array}{c}\text { Publications } \\
\text { (R.3) }\end{array}$ & $\begin{array}{l}\text { There is no } \\
\text { BIM } \\
\text { publication in } \\
\text { an article, } \\
\text { journal, } \\
\text { academic } \\
\text { periodical, or } \\
\text { similar. }\end{array}$ & $\begin{array}{l}\text { Sporadic BIM } \\
\text { publications, } \\
\text { without an } \\
\text { established } \\
\text { frequency, } \\
\text { mostly focused } \\
\text { on the HEI } \\
\text { internal events. }\end{array}$ & $\begin{array}{l}\text { Sporadic BIM } \\
\text { publications, } \\
\text { without an } \\
\text { established } \\
\text { frequency, but } \\
\text { with the reach } \\
\text { of regional and } \\
\text { national } \\
\text { seminars. }\end{array}$ & $\begin{array}{l}\text { Planned BIM } \\
\text { publications } \\
\text { with the reach } \\
\text { of regional and } \\
\text { national } \\
\text { seminars and } \\
\text { national } \\
\text { periodicals. }\end{array}$ & $\begin{array}{l}\text { Planned BIM } \\
\text { publications } \\
\text { with the reach } \\
\text { of international } \\
\text { periodicals. }\end{array}$ \\
\hline $\begin{array}{c}\text { Trained } \\
\text { students } \\
(\mathrm{R} .4)\end{array}$ & $\begin{array}{l}\text { No trained } \\
\text { student. }\end{array}$ & $\begin{array}{l}\text { Up to } 50 \\
\text { trained } \\
\text { students. }\end{array}$ & $\begin{array}{l}\text { Up to } 250 \\
\text { trained } \\
\text { students. }\end{array}$ & $\begin{array}{l}\text { Up to } 500 \\
\text { trained } \\
\text { students. }\end{array}$ & $\begin{array}{l}\text { Over } 500 \\
\text { trained } \\
\text { students. }\end{array}$ \\
\hline
\end{tabular}

Table 7 - m²BIM-HEI (Technology Field) (Continues...)

\begin{tabular}{|c|c|c|c|c|c|}
\hline NM & $\begin{array}{l}\text { Pre-BIM } \\
5 \mathrm{pts}\end{array}$ & $\begin{array}{l}\text { Initial } \\
20 \mathrm{pts}\end{array}$ & $\begin{array}{c}\text { Defined } \\
30 \mathrm{pts}\end{array}$ & $\begin{array}{c}\text { Integrated } \\
40 \mathrm{pts}\end{array}$ & $\begin{array}{l}\text { Optimized } \\
50 \mathrm{pts}\end{array}$ \\
\hline \multicolumn{6}{|c|}{$\begin{array}{l}\text { Technology } \\
\text { gical or physical, for the development of the BIM teaching. }\end{array}$} \\
\hline $\begin{array}{c}\text { Institutional } \\
\text { agreements } \\
\text { with } \\
\text { Software } \\
\text { developers } \\
\text { (T.1) }\end{array}$ & $\begin{array}{l}\text { There is no } \\
\text { institutional } \\
\text { agreement } \\
\text { with } \\
\text { software } \\
\text { developers. }\end{array}$ & $\begin{array}{l}\text { There is an } \\
\text { institutional } \\
\text { agreement with a } \\
\text { software } \\
\text { developer. (1 } \\
\text { item fulfilment) } \\
\text { 1. Software } \\
\text { provision for } \\
\text { HEI access; } \\
\text { 2. Software } \\
\text { provision for } \\
\text { student's } \\
\text { individual access } \\
\text { (outside HEI); } \\
\text { 3. Faculty staff } \\
\text { training program; } \\
\text { 4. Students' } \\
\text { training program. }\end{array}$ & $\begin{array}{l}\text { There is an } \\
\text { institutional } \\
\text { agreement with a } \\
\text { software } \\
\text { developer } \\
\text { (fulfilment of } 3 \\
\text { items) } \\
\text { 1. Software } \\
\text { provision for } \\
\text { HEI access; } \\
\text { 2. Software } \\
\text { provision for } \\
\text { student's } \\
\text { individual access } \\
\text { (outside HEI); } \\
\text { 3. Faculty staff } \\
\text { training } \\
\text { program; } \\
\text { 4. Students' } \\
\text { training program. }\end{array}$ & $\begin{array}{l}\text { There is an } \\
\text { institutional } \\
\text { agreement with a } \\
\text { software developer } \\
\text { (fulfilment of } 4 \\
\text { items) } \\
\text { 1. Software } \\
\text { provision for HEI } \\
\text { access; } \\
\text { 2. Software } \\
\text { provision for } \\
\text { student's individual } \\
\text { access (outside } \\
\text { HEI); } \\
\text { 3. Faculty staff } \\
\text { training program; } \\
\text { 4. Students' } \\
\text { training program. }\end{array}$ & $\begin{array}{l}\text { There are institutional } \\
\text { agreements with more } \\
\text { than one software } \\
\text { developer (fulfilment } \\
\text { of } 4 \text { items) } \\
\text { 1. Software provision } \\
\text { for HEI access; } \\
\text { 2. Software provision } \\
\text { for student's individual } \\
\text { access (outside HEI); } \\
\text { 3. Faculty staff training } \\
\text { program; } \\
\text { 4. Students' training } \\
\text { program. }\end{array}$ \\
\hline $\begin{array}{l}\text { Software } \\
\quad(\mathrm{T} .2)\end{array}$ & $\begin{array}{l}\text { There is no } \\
\text { installed } \\
\text { software. }\end{array}$ & $\begin{array}{l}\text { Installed } \\
\text { software in some } \\
\text { computers with } \\
\text { no institutional } \\
\text { control, nor } \\
\text { licence control, } \\
\text { nor institutional } \\
\text { monitoring. }\end{array}$ & $\begin{array}{l}\text { Installed } \\
\text { software in some } \\
\text { computers. } \\
\text { Simple } \\
\text { institutional } \\
\text { control over } \\
\text { installation and } \\
\text { software licence. }\end{array}$ & $\begin{array}{l}\text { Software installed } \\
\text { in all computers of } \\
\text { at least one student } \\
\text { computing lab. } \\
\text { This installation } \\
\text { occurs in an } \\
\text { institutionalized, } \\
\text { controlled, licenced } \\
\text { and monitored } \\
\text { way. }\end{array}$ & $\begin{array}{l}\text { Software installed in all } \\
\text { computers of all } \\
\text { student computing labs. } \\
\text { This installation occurs } \\
\text { in an institutionalized, } \\
\text { controlled, licenced } \\
\text { and monitored way. }\end{array}$ \\
\hline
\end{tabular}


Table 7 - m²BIM-HEI (Technology Field) (continued)

\begin{tabular}{|c|c|c|c|c|c|}
\hline $\mathbf{N M}$ & $\begin{array}{l}\text { Pre-BIM } \\
5 \mathrm{pts}\end{array}$ & $\begin{array}{l}\text { Initial } \\
20 \text { pts }\end{array}$ & $\begin{array}{c}\text { Defined } \\
30 \mathrm{pts} \\
\end{array}$ & $\begin{array}{c}\text { Integrated } \\
40 \mathrm{pts} \\
\end{array}$ & $\begin{array}{c}\text { Optimized } \\
50 \mathrm{pts} \\
\end{array}$ \\
\hline \multicolumn{6}{|c|}{$\begin{array}{l}\text { Technology } \\
\text { gical or physical, for the development of the BIM teaching. }\end{array}$} \\
\hline $\begin{array}{c}\text { Hardware } \\
\text { developer } \\
\text { Institutional } \\
\text { Agreements } \\
\text { (T.3) }\end{array}$ & $\begin{array}{l}\text { There is no } \\
\text { institutional } \\
\text { agreement } \\
\text { with } \\
\text { hardware } \\
\text { developers. }\end{array}$ & $\begin{array}{l}\text { There is an } \\
\text { institutional } \\
\text { agreement with a } \\
\text { hardware } \\
\text { developer. (1 } \\
\text { item fulfilment) } \\
\text { 1. Hardware } \\
\text { provision for } \\
\text { HEI access; } \\
\text { 2. Hardware } \\
\text { provision for } \\
\text { students; } \\
\text { 3. Faculty staff } \\
\text { training program; } \\
\text { 4. Students' } \\
\text { training program. } \\
\text { 5. Maintenance; } \\
\text { 6. Replacement } \\
\text { and } \\
\text { Modernization } \\
\text { program. }\end{array}$ & $\begin{array}{l}\text { There is an } \\
\text { institutional } \\
\text { agreement with a } \\
\text { hardware } \\
\text { developer. (2 } \\
\text { items fulfilment) } \\
\text { 1. Hardware } \\
\text { provision for } \\
\text { HEI access; } \\
\text { 2. Hardware } \\
\text { provision for } \\
\text { students; } \\
\text { 3. Faculty staff } \\
\text { training } \\
\text { program; } \\
\text { 4. Students' } \\
\text { training program. } \\
\text { 5. Maintenance; } \\
6 . \text { Replacement } \\
\text { and } \\
\text { Modernization } \\
\text { program. }\end{array}$ & $\begin{array}{l}\text { There is an } \\
\text { institutional } \\
\text { agreement with a } \\
\text { hardware } \\
\text { developer. (4 items } \\
\text { fulfilment) } \\
\text { 1. Hardware } \\
\text { provision for HEI } \\
\text { access; } \\
\text { 2. Hardware } \\
\text { provision for } \\
\text { students; } \\
\text { 3. Faculty staff } \\
\text { training program; } \\
\text { 4. Students' } \\
\text { training program. } \\
\text { 5. Maintenance; } \\
\text { 6. Replacement } \\
\text { and Modernization } \\
\text { program. }\end{array}$ & $\begin{array}{l}\text { There is institutional } \\
\text { agreement with } \\
\text { hardware developers. } \\
\text { (over } 4 \text { items } \\
\text { fulfilment) } \\
\text { 1. Hardware provision } \\
\text { for HEI access; } \\
\text { 2. Hardware provision } \\
\text { for students; } \\
\text { 3. Faculty staff training } \\
\text { program; } \\
\text { 4. Students' training } \\
\text { program. } \\
\text { 5. Maintenance; } \\
\text { 6. Replacement and } \\
\text { Modernization } \\
\text { program. }\end{array}$ \\
\hline $\begin{array}{l}\text { Hardware } \\
\quad(\mathrm{T} .4)\end{array}$ & $\begin{array}{l}\text { There are no } \\
\text { proper } \\
\text { hardwares } \\
\text { for the use } \\
\text { of BIM } \\
\text { softwares, } \\
\text { making it } \\
\text { impossible } \\
\text { or difficult } \\
\text { to use. }\end{array}$ & $\begin{array}{l}\text { Proper hardware } \\
\text { in only some } \\
\text { working stations } \\
\text { in a student lab. } \\
\text { Hardware } \\
\text { acquisitions are } \\
\text { done without any } \\
\text { plan that goes } \\
\text { with the uses and } \\
\text { intended BIM } \\
\text { softwares. }\end{array}$ & $\begin{array}{l}\text { Proper } \\
\text { hardwares in a } \\
\text { student } \\
\text { computing lab. } \\
\text { Hardware } \\
\text { acquisitions are } \\
\text { done without any } \\
\text { plan that goes } \\
\text { with the uses and } \\
\text { intended BIM } \\
\text { softwares. }\end{array}$ & $\begin{array}{l}\text { Proper hardwares } \\
\text { in all student } \\
\text { computing labs. } \\
\text { Hardware } \\
\text { acquisitions are } \\
\text { done according to a } \\
\text { plan that goes with } \\
\text { the uses and } \\
\text { intended BIM } \\
\text { softwares. }\end{array}$ & $\begin{array}{l}\text { Proper hardwares in all } \\
\text { student computing labs. } \\
\text { Hardware acquisitions } \\
\text { are done according to a } \\
\text { plan that goes with the } \\
\text { uses and intended BIM } \\
\text { softwares. } \\
\text { There is a replacement } \\
\text { and improvement } \\
\text { program that goes } \\
\text { along with the BIM } \\
\text { planning. }\end{array}$ \\
\hline $\begin{array}{l}\text { Infrastructure } \\
\text { (T.5) }\end{array}$ & $\begin{array}{l}\text { There is no } \\
\text { physical } \\
\text { space for } \\
\text { the use of } \\
\text { BIM } \\
\text { hardwares } \\
\text { and } \\
\text { softwares. }\end{array}$ & $\begin{array}{l}\text { Computing labs } \\
\text { with BIM } \\
\text { softwares and } \\
\text { hardwares } \\
\text { working stations. } \\
\text { The final goal of } \\
\text { the space is not } \\
\text { BIM teaching } \\
\text { and it is shared } \\
\text { with other uses } \\
\text { and lectures. }\end{array}$ & $\begin{array}{l}\text { Computing labs } \\
\text { with individual } \\
\text { working stations } \\
\text { with BIM } \\
\text { softwares and } \\
\text { hardwares } \\
\text { aiming } \\
\text { exclusively at } \\
\text { BIM teaching. }\end{array}$ & $\begin{array}{l}\text { BIM teaching } \\
\text { spaces with } \\
\text { individualized } \\
\text { hardwares and } \\
\text { accomodations. } \\
\text { Space with } \\
\text { interactive } \\
\text { infrastructure and } \\
\text { information } \\
\text { sharing. BIM } \\
\text { teaching } \\
\text { exclusively. }\end{array}$ & $\begin{array}{l}\text { BIM teaching spaces } \\
\text { with individualized } \\
\text { hardwares and } \\
\text { accomodations. } \\
\text { Space with interactive } \\
\text { infrastructure and } \\
\text { information sharing. } \\
\text { BIM teaching } \\
\text { exclusively. } \\
\text { Active and } \\
\text { Collaborative learning } \\
\text { environment with a } \\
\text { high level of student } \\
\text { engagement. }\end{array}$ \\
\hline
\end{tabular}

Maturity is measured by the Maturity Degree (MD), through the Maturity Index (MI). The Maturity Degree consists of an arithmetic average of the 16 evaluated items (the sum of the scores divided by 16), with a maximum score of 50 points. The Maturity Index is a percentage value, in which the Maturity Degree is referenced to the maximum score (100\%). The BIM Maturity Level is obtained through the relationship between Maturity Index and Maturity Degree (RODRIGUES, 2018), illustrated in Table 8. 
Table 8 - BIM Maturity Degree, Maturity Index and Maturity Level Relation

\begin{tabular}{c|c|c|c}
\hline \multicolumn{3}{c}{ BIM MATURITY DEGREE } \\
\hline & Maturity Index & Maturity Level & Text Classification \\
\hline A & $0-19 \%$ & Pre-BIM & No maturity \\
B & $20-39 \%$ & Initial & Low maturity \\
C & $40-59 \%$ & Defined & Medium maturity \\
D & $60-79 \%$ & Integrated & High maturity \\
E & $80-100 \%$ & Optimized & Very high maturity \\
\hline
\end{tabular}

Source: adapted from Rodrigues (2018).

\section{BIM use characterization}

When asked about the Federal Decree 9.337 (BRASIL, 2018), 46\% of course coordinators informed that they were not aware of the decree content. This representative number raises a red flag about the adherence to the strategic actions and specific objectives of the BIM BR Strategy. It is essential that there is an understanding of the decree and that the HEIs have the responsibility to prepare future professionals for this demand and market requirement.

On the other hand, the coordinators who said they were aware of the decree, were asked about how they intend to put it into practice by $2021.57 \%$ of them responded that the courses intend to offer disciplines in BIM, while $36 \%$ did not know how to report the actions to be developed. This last data shows a myopic view both of the BIM implementation process and of BIM concept. Most HEIs aim to offer "BIM Disciplines", mistakenly envisioning disciplines with a focus on the software.

The contact with BIM throughout the undergraduate course is present in $88 \%$ of the courses, in which the coordinators stated that this contact occurs in at least one moment along the undergraduate course. Among the types of contact, the most prevalent is lectures $(73 \%)$, followed by offers of software extension courses, as shown in Figure 2.

When analyzing the barriers faced on implementing BIM, it is clear that they are shared among the courses that have already implemented it, like us, and that have not implemented it (as shown in Table 9). The main barrier is related to the lack of faculty staff training, followed directly by the faculty's lack of interest in adopting it.

It is observed that the barriers diagnosis to the adoption of BIM meets the barriers identified in the literature (RUSCHEL; ANDRADE; MORAIS, 2013; CHECCUCCI, 2014; SACKS; PIKAS, 2013; SABONGI, 2009) mentioned previously in this study. Noticing the Brazilian use of BIM growth in the last decade, most prominently in the last three years, it is a great challenge to train the faculty staff of the HEIs. The professor possesses the main role in the teaching-learning process, which requires he/she to have total mastery over the subject. The lack of professor training leads to the inexistence of the BIM theme in the classroom, since the professor does not have enough knowledge to address the subject. The implementation of training programs or incentives for professors becomes an interesting alternative to solve this problem. However, it is possible to encounter resistance from professors in seeking knowledge in new technologies and methodologies. This fact has been identified in the research.

Altogether, $58 \%$ of the coordinators stated that the professors of the course have little or no knowledge in BIM, while 35\% said they had an average knowledge and $8 \%$ had an advanced level of knowledge, highlighting the need to create faculty training and incentive programs for HEIs.

In an analysis of professors' responsibilities, not viewing BIM as a priority in the curriculum shows a lack of awareness, articulation, or knowledge on the part of the Structuring Teaching Nucleus (STN) of the courses, which is responsible for the changes in the curricular grades and has the ability to insert BIM in disciplines. At the same time, the lack of incentive from the higher levels of hierarchy of the HEI is mainly related to private institutions, since the request and distribution of resources and actions must follow the guidelines and strategic planning of the top level hierarchy. Such lack of incentive can be interpreted as natural in any process of implementing a new methodology and/or technology. The support from top hierarchy levels in these institutions is essential and must be obtained through an awareness of the benefits of implementation and the requirements at the legislative and market levels, BIM must be viewed as an action at the forefront of teaching excellence. 
Regarding the insertion of BIM in the disciplines, $90 \%$ of the courses that claimed to adopt BIM, indicated the use of BIM in disciplines. Table 10 shows the list of BIM uses (SUCCAR; SALEEB; SHER, 2016) developed in the disciplines. Altogether, seven BIM uses were mentioned in addition to the introduction. Despite a diversity of use, it is observed that $46 \%$ of citations do not refer to a BIM use itself, but rather to a BIM introduction. The most cited BIM use $(22.50 \%)$ is Modeling, followed by Simulations $(8.40 \%)$, and Dimensioning and Planning (7.00\%). Disciplines were grouped into themes as a way to bring together the various related disciplines. Table 11 shows the disciplines that have the introduction of BIM.

Figure 2 - Types of BIM contact in undergraduate courses of Architecture and Urbanism and Civil Engineering in Ceará State

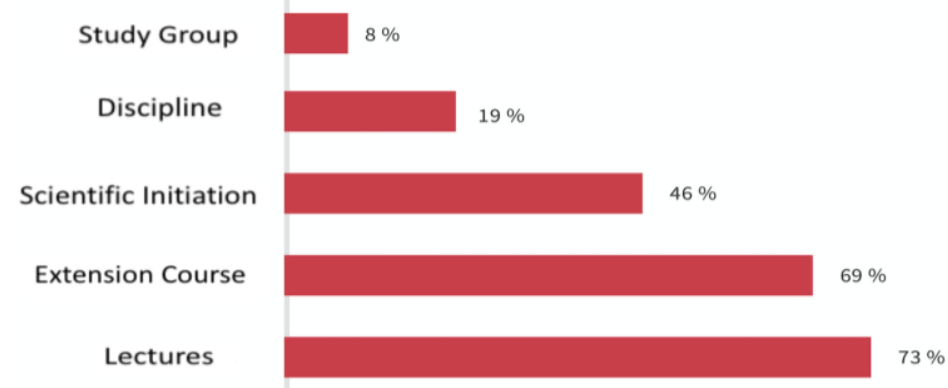

Table 9 - Comparison of barriers for BIM adoption in undergraduate courses of Architecture and Urbanism and Civil Engineering

\begin{tabular}{c|c|c}
\hline Barrier for BIM adoption & $\begin{array}{c}\text { Undergraduate courses that } \\
\text { have not adopted BIM }\end{array}$ & $\begin{array}{c}\text { Undergraduate courses } \\
\text { that have adopted BIM }\end{array}$ \\
\hline Lack of faculty staff training & $64 \%$ & $90 \%$ \\
\hline Lack of faculty staff interest & - & $52 \%$ \\
\hline Lack of technological resources & $9 \%$ & $43 \%$ \\
\hline Resistance to a new methodology/technology & $9 \%$ & $43 \%$ \\
\hline BIM is not viewed as a curriculum priority & $45 \%$ & $33 \%$ \\
\hline Lack of incentive by the higher positions \\
inside the HEI & $36 \%$ & $24 \%$ \\
\hline Lack of student interest & - & $14 \%$ \\
\hline Lack of market incentive and/or demand & - & $10 \%$ \\
\hline Lack of interest by the HEI & - & $5 \%$ \\
\hline Initial Investment & $9 \%$ & - \\
\hline Inexistence of requirement/obligation & $9 \%$ & - \\
\hline Students have contact with BIM externally & $9 \%$ & - \\
\hline
\end{tabular}

Table 10 - BIM uses relation developed in disciplines

\begin{tabular}{|c|c|c|c|c|c|c|c|c|}
\hline $\begin{array}{l}\text { Disciplines } \\
\text { group }\end{array}$ & $\begin{array}{l}\text { Intro- } \\
\text { duction }\end{array}$ & $\begin{array}{l}\text { Mode- } \\
\text { ling }\end{array}$ & $\begin{array}{c}\text { Dimensio- } \\
\text { ning }\end{array}$ & $\begin{array}{l}\text { Document } \\
\text { Generation }\end{array}$ & $\begin{array}{l}\text { Quanti- } \\
\text { tative }\end{array}$ & $\begin{array}{c}\text { Plan- } \\
\text { ning }\end{array}$ & $\begin{array}{c}\text { Simula- } \\
\text { tions }\end{array}$ & $\begin{array}{l}\text { Compati- } \\
\text { bilization }\end{array}$ \\
\hline & 33 & 16 & 5 & 2 & 1 & 5 & 6 & 3 \\
\hline $\begin{array}{l}\text { Building } \\
\text { Systems } \\
\end{array}$ & 4 & 3 & 1 & - & 1 & 1 & 1 & - \\
\hline $\begin{array}{c}\text { Construction } \\
\text { Materials }\end{array}$ & 5 & 1 & - & - & - & 1 & - & 1 \\
\hline $\begin{array}{c}\text { Construction } \\
\text { Techniques }\end{array}$ & 5 & 1 & 1 & - & - & - & 1 & 1 \\
\hline
\end{tabular}


It is observed that BIM is present in the disciplines in an introductory way, the vast majority of them do not involve model development or other BIM uses. This finding plays a great role in understanding the current level of BIM in the courses of Architecture and Urbanism and Civil Engineering in HEIs of Ceará state. It shows that although there are BIM initiatives in the undergraduate courses, most are still at an introductory level. This analysis is corroborated by Table 11 , which shows that $61 \%$ of the disciplines in which BIM is employed are in disciplines of Computer Aided Design, Graphic Representation, Applied Drawing and Graphic Expression, that is, in drawing disciplines, and not project ones. This fact shows an under-use of BIM.

As a way to deepen the understanding of how BIM is approached in the disciplines, it was obtained that in $86 \%$ of the undergraduate courses BIM is approached as an introductory content, without further studies or applications; $71 \%$ said they use BIM as a tool; $57 \%$ considered BIM a methodology within their syllabi; and $38 \%$ adopted BIM to work on skills and competences. The main software adopted is Revit Architecture, adopted in $77 \%$ of the courses, followed by ArchiCAD, with $46 \%$, and TQS with $30 \%$, in addition to 8 other softwares, as shown in Table 12.

The choice of a certain software by the HEI may be related to market demands, faculty knowledge, as well as due to partnerships with software developers, as mentioned previously. This way, $42 \%$ of the HEI course coordinators interviewed stated that the course has an agreement or partnership with one or more software developers. The Autodesk company leads this initiative, it responds to $66 \%$ of agreements in courses that have some type of agreement and $23 \%$ of the interviewed courses. In second place comes Bentley with $34 \%$ of agreements among the courses that have partnership and $12 \%$ of interviewed courses. The partnership with software developers benefits the HEIs with the provision of BIM software, and training for professors and students, as shown previously in Table 9.

Table 11 - Disciplines with BIM introduction

\begin{tabular}{c|c}
\hline Disciplines & Courses \\
\hline Computer aided drawing/Graphic Representation/Applied Drawing/ Graphic Expression & 13 \\
Architectural Project & 8 \\
Building Construction/Building Techniques/Building Industry & 4 \\
Management/Building execution planning & 3 \\
Urban Project & 2 \\
Plumbing and drainage Systems & 2 \\
Electrical Wiring & 1 \\
Concrete Structure & 1 \\
\hline
\end{tabular}

Table 12 - BIM Softwares used in Architecture and Urbanism and Civil Engineering undergrad courses in Ceará state

\begin{tabular}{c|c|c|c}
\hline Softwares & Total & $\begin{array}{c}\text { Architecture and } \\
\text { Urbanism }\end{array}$ & $\begin{array}{c}\text { Civil } \\
\text { Engineering }\end{array}$ \\
\hline Revit Architecture & $77 \%$ & 7 & 13 \\
ArchiCAD & $46 \%$ & 5 & 7 \\
TQS & $30 \%$ & 3 & 5 \\
Navisworks & $15 \%$ & - & 4 \\
Revit Structural & $15 \%$ & - & 4 \\
Autodesk Green Building Studio & $15 \%$ & 1 & 3 \\
Bentley Architecture & $11 \%$ & 1 & 2 \\
Autodesk Ecotect Analysis & $7 \%$ & - & - \\
Vectorworks Architect & $3 \%$ & 1 & - \\
Synchro & $3 \%$ & - & 3 \\
Tekla Structures & $3 \%$ & 1 & \\
Does not know & $15 \%$ & 1 & \\
\hline
\end{tabular}


In addition to teaching, BIM is present in the scientific initiation, as previously illustrated in Figure 2, in which $46 \%$ of course coordinators stated that the students have contact with BIM through it. An important data for HEIs is the number of publications made from studies developed locally. In this case, $33.33 \%$ of course coordinators stated that they had published a scientific article in an academic or periodical event about BIM use. Another BIM initiative developed by the Architecture and Urbanism and Civil Engineering courses in the state of Ceará is the academic extension, which $62 \%$ of the courses claim to have it. Among the actions, we highlight extension courses (54\%), project offices $(38 \%)$, among other activities $(8 \%)$.

\section{BIM Maturity}

Based on course coordinators' responses, the information was compiled, processed and inserted into the $\mathrm{m}$ BIM-HEI, generating a score for each course, as shown in Table 13, making it possible to calculate the Degree of Maturity and the Maturity Index.

Through m BIM-HEI, we can observe that the Civil Engineering and Architecture and Urbanism undergraduate courses have a low degree of maturity in the evaluation criteria, with an average of 15.87 points. As we can notice through a macro view in Figure 3 that presents the average score for each criterion of all courses. Only a quarter of the criteria reached over 20 points, showing that, on average, there is a low performance of HEIs in relation to BIM use. The most scored criterion was "Teaching BIM", with 25.38 points, with most of its content offered involving Introduction to BIM and the software use. However, although it has the best performance among its peers, its score is still low, being classified as Low Maturity BIM. The criterion with the worst score was "Institutional agreements with hardware manufacturers" followed by "Faculty Training", with 6.15 and 7.88 points respectively.

In an analysis of the BIM Fields defined by m BIM-HEI, we see that the Maturity Degree among the three fields is very similar, Technology (16.38 points), Policy (16.62 points), and Processes (13.94 points), as shown in Figure 4. In a first analysis, we see that BIM Fields have a low Maturity Degree, with no prominence among them, showing that the problems related to the low BIM maturity or even the lack of maturity are present in all fields, requiring a lot of action and work from the HEIs to increase the maturity.

Table 13 - Architecture and Urbanism and Civil Engineering undergraduate courses BIM Maturity Index

\begin{tabular}{|c|c|c|c|c|c|c|c|c|c|c|c|c|c|c|c|c|c|c|}
\hline \multirow{2}{*}{ Courses } & \multicolumn{7}{|c|}{ Policy } & \multicolumn{4}{|c|}{ Processes } & \multicolumn{5}{|c|}{ Technology } & \multirow{2}{*}{$\begin{array}{c}\text { Maturity } \\
\text { Degree }\end{array}$} & \multirow{2}{*}{$\begin{array}{c}\text { Maturity } \\
\text { Index }\end{array}$} \\
\hline & P.1 & P.2 & P.3 & P.4 & P.5 & P.6 & P.7 & R.1 & R.2 & R.3 & R.4 & T.1 & T.2 & T.3 & T.4 & T.5 & & \\
\hline 1 & 5 & 10 & 20 & 15 & 5 & 5 & 5 & 5 & 5 & 5 & 5 & 5 & 20 & 5 & 20 & 20 & 9,68 & $19,38 \%$ \\
\hline 2 & 5 & 30 & 5 & 5 & 5 & 5 & 5 & 5 & 5 & 5 & 5 & 5 & 5 & 5 & 5 & 20 & 7,5 & $15,00 \%$ \\
\hline 3 & 20 & 30 & 20 & 20 & 5 & 30 & 30 & 15 & 25 & 5 & 5 & 5 & 20 & 5 & 20 & 20 & 17,18 & $34,38 \%$ \\
\hline 4 & 20 & 30 & 50 & 50 & 50 & 30 & 50 & 15 & 20 & 5 & 25 & 40 & 30 & 5 & 30 & 20 & 29,37 & $\mathbf{5 8 , 7 5 \%}$ \\
\hline 5 & 5 & 15 & 5 & 10 & 5 & 5 & 5 & 5 & 15 & 5 & 15 & 5 & 15 & 5 & 15 & 20 & 9,37 & $18,75 \%$ \\
\hline 6 & 5 & 30 & 20 & 40 & 30 & 5 & 30 & 15 & 30 & 5 & 15 & 25 & 20 & 5 & 20 & 20 & 19,68 & $39,38 \%$ \\
\hline 7 & 5 & 30 & 20 & 40 & 5 & 30 & 20 & 15 & 35 & 25 & 20 & 5 & 30 & 5 & 30 & 20 & 20,93 & $41,88 \%$ \\
\hline 8 & 5 & 15 & 5 & 10 & 5 & 10 & 5 & 5 & 5 & 15 & 5 & 10 & 20 & 5 & 20 & 10 & 9,37 & $18,75 \%$ \\
\hline 9 & 5 & 30 & 20 & 40 & 20 & 5 & 30 & 15 & 20 & 5 & 25 & 5 & 30 & 5 & 30 & 20 & 19,06 & $38,13 \%$ \\
\hline 10 & 5 & 30 & 20 & 20 & 20 & 30 & 5 & 15 & 25 & 5 & 20 & 40 & 30 & 5 & 30 & 20 & 20 & $40,00 \%$ \\
\hline 11 & 5 & 20 & 5 & 40 & 40 & 5 & 30 & 15 & 20 & 25 & 15 & 5 & 30 & 5 & 30 & 20 & 19,37 & $38,75 \%$ \\
\hline 12 & 5 & 20 & 5 & 40 & 20 & 30 & 20 & 5 & 20 & 25 & 50 & 5 & 30 & 5 & 30 & 20 & 20,62 & $41,25 \%$ \\
\hline 13 & 5 & 30 & 20 & 30 & 5 & 30 & 40 & 15 & 20 & 5 & 25 & 5 & 30 & 5 & 30 & 20 & 19,68 & $39,38 \%$ \\
\hline 14 & 5 & 5 & 5 & 5 & 5 & 5 & 5 & 5 & 5 & 5 & 5 & 5 & 5 & 5 & 5 & 20 & 5,93 & $11,88 \%$ \\
\hline 15 & 5 & 30 & 20 & 30 & 30 & 5 & 5 & 15 & 25 & 5 & 45 & 30 & 30 & 5 & 30 & 20 & 20,62 & $41,25 \%$ \\
\hline 16 & 5 & 30 & 10 & 40 & 30 & 5 & 5 & 15 & 20 & 5 & 5 & 5 & 20 & 5 & 20 & 20 & 15 & $30,00 \%$ \\
\hline 17 & 5 & 30 & 20 & 30 & 5 & 5 & 20 & 20 & 25 & 25 & 15 & 20 & 30 & 5 & 30 & 20 & 19,06 & $38,13 \%$ \\
\hline 18 & 5 & 20 & 5 & 5 & 5 & 20 & 5 & 5 & 10 & 5 & 10 & 5 & 20 & 5 & 20 & 10 & 9,68 & $19,38 \%$ \\
\hline 19 & 20 & 30 & 5 & 20 & 5 & 5 & 20 & 5 & 20 & 25 & 20 & 5 & 30 & 5 & 30 & 20 & 16,56 & $33,13 \%$ \\
\hline 20 & 5 & 30 & 5 & 20 & 5 & 5 & 40 & 15 & 25 & 5 & 5 & 30 & 30 & 5 & 30 & 20 & 17,18 & $\mathbf{3 4 , 3 8 \%}$ \\
\hline 21 & 20 & 30 & 20 & 30 & 30 & 20 & 30 & 15 & 25 & 25 & 20 & 20 & 30 & 5 & 30 & 20 & 23,12 & $46,25 \%$ \\
\hline 22 & 20 & 30 & 20 & 40 & 30 & 5 & 40 & 15 & 25 & 5 & 50 & 20 & 30 & 35 & 30 & 20 & 25,93 & $51,88 \%$ \\
\hline 23 & 5 & 20 & 5 & 30 & 20 & 5 & 5 & 5 & 5 & 5 & 5 & 5 & 5 & 5 & 5 & 20 & 9,37 & $18,75 \%$ \\
\hline 24 & 5 & 20 & 5 & 20 & 5 & 5 & 20 & 15 & 20 & 5 & 5 & 5 & 5 & 5 & 5 & 10 & 9,68 & $19,38 \%$ \\
\hline 25 & 5 & 15 & 5 & 15 & 5 & 5 & 5 & 15 & 5 & 5 & 5 & 5 & 20 & 5 & 15 & 20 & 9,37 & $18,75 \%$ \\
\hline 26 & 5 & 15 & 5 & 15 & 5 & 5 & 5 & 15 & 5 & 5 & 5 & 20 & 10 & 5 & 20 & 10 & 9,37 & $18,75 \%$ \\
\hline
\end{tabular}

Note: 10-pre-BIM;

20-initial;

30-defined;

40-integrated; and

50-optimized. 
Figure 3 - BIM Maturity Degree average of $\mathrm{m}^{2} \mathrm{BIM}-\mathrm{HEI}$ criteria

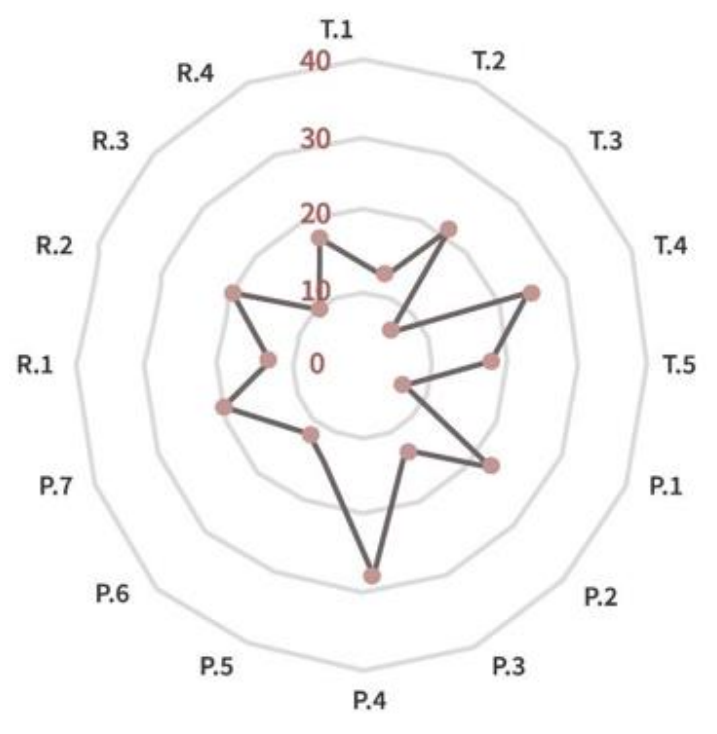

Figure 4 - Average undergraduate course BIM Maturity Level - BIM Fields

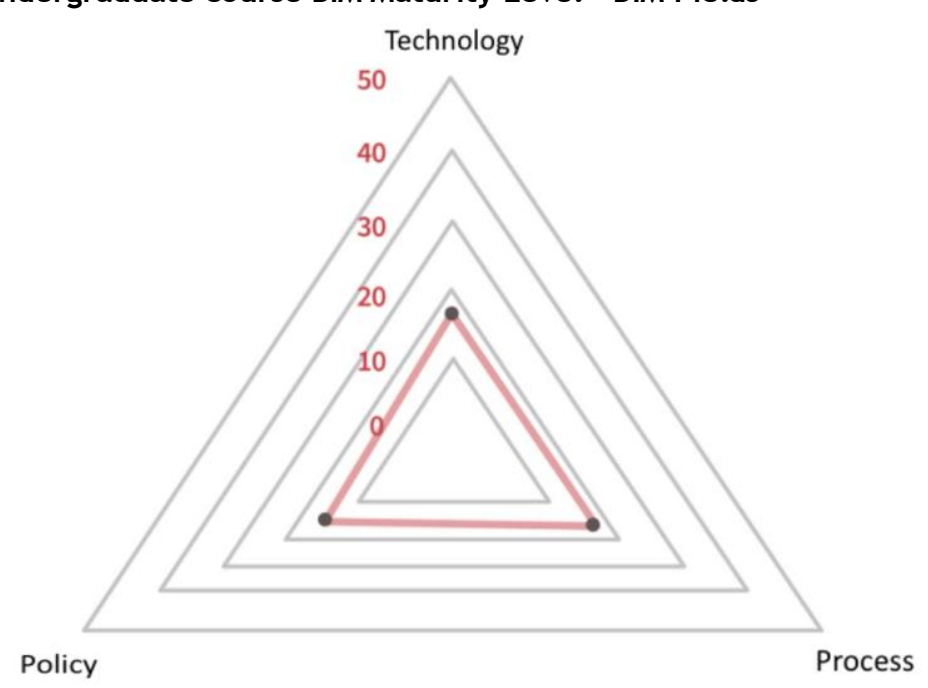

Note: 10 -pre-BIM;

20-initial;

30-defined;

40-integrated; and

50-optimized.

When analyzing the Maturity Degree of each criterion, it is possible to calculate the Maturity Index and relate it to the Maturity Level for each one, as shown in Table 3, thus working for an individual analysis. Table 14 shows this relationship. There are two criteria classified as Pre-BIM, that is, no maturity. Most of the criteria are at the Initial level, when there is low maturity, while 4 criteria are at the Defined level, considered medium maturity.

Of the 26 Civil Engineering and Architecture and Urbanism undergraduate courses analysed in this research, $39 \%$ are considered at the Pre-BIM level, with no BIM maturity; 35\% at the Initial level, with low maturity; and $26 \%$ are at a Defined maturity level, with medium maturity, as shown in Figure 5. With this result, we can state that $74 \%$ of the Engineering and Architecture and Urbanism undergraduate courses have low BIM maturity or do not have maturity at all. 
Table 14 - m²BIM-HEI criteria through Maturity Levels

\begin{tabular}{|c|c|c|c|c|}
\hline Code & Criterion & Maturity Degree & Maturity Index & Maturity Level \\
\hline T.3 & $\begin{array}{l}\text { Hardware developers } \\
\text { institutional agreements }\end{array}$ & 6,15 & $12 \%$ & \multirow{2}{*}{$\begin{array}{c}\text { Pre-BIM } \\
\text { No Maturity }\end{array}$} \\
\hline P.1 & Faculty Training & 7,88 & $16 \%$ & \\
\hline R.3 & Publications & 10 & $20 \%$ & \multirow{10}{*}{$\begin{array}{c}\text { Initial } \\
\text { Low Maturity }\end{array}$} \\
\hline R.1 & BIM uses & 11,73 & $23 \%$ & \\
\hline P.6 & Scientific Initiation & 12,11 & $24 \%$ & \\
\hline T.1 & $\begin{array}{c}\text { Software developers } \\
\text { institutional agreements }\end{array}$ & 12,88 & $26 \%$ & \\
\hline P.3 & BIM Institutional View & 13,26 & $27 \%$ & \\
\hline P.5 & Academic Extension & 15,19 & $30 \%$ & \\
\hline R.4 & Trained students & 16,34 & $33 \%$ & \\
\hline R.2 & BIM Disciplines & 17,69 & $35 \%$ & \\
\hline T.5 & Infrastructure & 18,46 & $37 \%$ & \\
\hline P.7 & Federal Decree 9.337:2018 & 18,46 & $37 \%$ & \\
\hline T.2 & Softwares & 22,11 & $44 \%$ & \multirow{4}{*}{$\begin{array}{l}\text { Defined } \\
\text { Medium } \\
\text { Maturity }\end{array}$} \\
\hline T.4 & Hardware & 22,30 & $45 \%$ & \\
\hline P.2 & Faculty BIM Engagement & 24,03 & $48 \%$ & \\
\hline P.4 & BIM Teaching & 25,38 & $51 \%$ & \\
\hline
\end{tabular}

Figure 5 - Ceará State Architecture and Urbanism and Civil Engineering undergraduate courses BIM Maturity

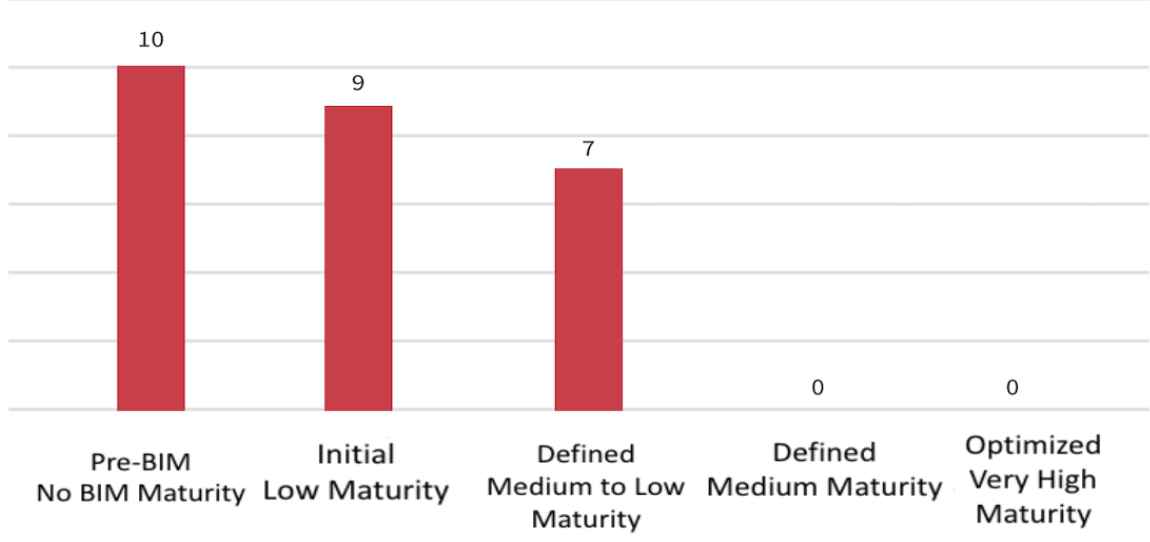

\section{Conclusion}

The present research had an exploratory profile, filling a gap in the literature by proposing a theoretical model of BIM maturity matrix designed to evaluate the HEIs and measure their BIM maturity.

A great number of undergraduate courses (46\%) are unaware of the Federal Decree 9.337 (BRASIL, 2018), unaligned with the BIM BR Strategy which provides for the BIM dissemination and teaching. A distorted understanding is observed on the part of undergraduate course coordinators that have not yet adopted BIM at their institutions but that intend to. All course coordinators mentioned that they are focused on offering disciplines that aim at the use of BIM software.

The disciplines with the greatest adoption of BIM are related to graphic representation, using BIM as a design tool and not as a design methodology. In relation to the developed uses, most of them are related only to the Introduction and some Modeling initiatives, with no collaboration or interoperability applications.

In all, seven HEIs presented a Defined level, nine are at an Initial level and ten at the Pre-BIM level, therefore with no maturity level at all. It is observed that although there are seven HEIs at a Defined level,

146 Böes, J. S.; Barros Neto, J. De P.; Lima, M. M. X. de 
only one Civil Engineering undergraduate course has BIM institutionalized and formalized in the curriculum, where BIM is present in several disciplines in an integrated way, while the others are characterized by professors' individual initiatives, without engagement with peers or formalization with the curricula.

It can be concluded that the major obstacle to the adoption of BIM is found in the human capital, either through the absence of trained professors, or through their resistance to seek training, which is the greatest challenge for the HEIs.

This study will work as a milestone in Ceará state BIM maturity, where, for the first time, a measurement has been presented, serving as basis for actions of implementation and dissemination, allowing a continuous measurement of HEIs' performance regarding the implementation of BIM in the student curricular matrix of Civil Engineering and Architecture and Urbanism undergraduate courses.

The results of the present study made it possible to complement other BIM maturity surveys in the building industry sector in Ceará state, in order to delineate the current scenario and, based on this panorama, propose a BIM implementation plan for the civil building industry.

Finally, it is foreseen that $\mathrm{m}$ BIM-HEI can be incorporated with new criteria for future studies, such as: information sharing in the Technology field, and skill levels in the Process field.

\section{References}

ANDRADE, R. A. Implementação do BIM no ensino: adequação de matrizes curriculares de cursos de arquitetura através da identificação de permeabilidades de conteúdo. Juiz de Fora, 2018. 198f. Dissertação (Mestrado em Ambiente Construído) - Programa de Pós-Graduação em Ambiente Construído, Universidade Federal de Juiz de Fora, Juiz de Fora, 2018.

AZHAR, S. Building Information Modeling (BIM): trends, benefits, risks and challenges for the AEC Industry. Leadership Management in Engineering, v. 11, n. 3, p. 241-252, 2011.

BARISON, M.; SANTOS, E. Ensino de BIM: tendências atuais no cenário internacional. Gestão \& Tecnologia de Projetos, São Carlos, v. 6, n. 2, p. 67-80, dez. 2011.

BASTO, P. E. de A.; LORDSLEEM JUNIOR, A. C. O ensino de BIM em curso de graduação em engenharia civil em uma universidade dos EUA: estudo de caso. Ambiente Construído, Porto Alegre, v. 16, n. 4, p. 45-61, out./dez. 2016.

BECERIK-GERBER, B.; KU, K.; JAZIZADEH, F. BIM: enabled virtual and collaborative construction engineering and management. Journal of Professional Issues in Engineering Education and Practice, v. 138, n. 3, p. 234-245, jul. 2012.

BEW, M.; RICHARDS, M. Bew-Richards BIM Maturity Model. 2008. Available: https://www.pic.org.uk/en/publications/avanti/index.cfm. Access: 15 dec. 2020.

BIMSCORE. bimSCORE. 2009. Disponível em: www.bimscore.com;index.php/welcome. Acesso em: 10 mar. 2019.

BÖES, J. S.; LIMA, M. M. X.; BARROS NETO, J. P. Identificação dos stakeholders envolvidos no processo de desenvolvimento de projetos na cadeia da construção civil do estado do Ceará: o primeiro passo para adoção do BIM. In: ENCONTRO NACIONAL DE TECNOLOGIA DO AMBIENTE CONSTRUÍDO, 18., Foz do Iguaçu, 2018. Anais [...] Foz do Iguaçu: ANTAC, 2018.

BÖES, J. S. Proposta de plano de implantação do BIM na indústria da construção civil. Fortaleza, 2019. 281 f. Dissertação (Mestrado em Engenharia Civil) - Universidade Federal do Ceará, Fortaleza, 2019.

BRASIL. Decreto n. 10.306, de 2 de Abril de 2020. Estabelece a utilização do Building Information Modelling na execução direta ou indireta de obras e serviços de engenharia realizada pelos órgãos e pelas entidades da administração pública federal, no âmbito da Estratégia Nacional de Disseminação do Building Information Modelling - Estratégia BIM BR, instituída pelo Decreto n ${ }^{\circ}$ 9.983, de 22 de agosto de 2019. Diário Oficial da União, Brasília, Edição 65, Seção, 1, p. 5, abr. 2020.Atos do Poder Executivo. 
BRASIL. Decreto n. 9.337, de 17 de maio de 2018. Institui a Estratégia de Disseminação do Building Information Modelling. Diário Oficial da União, Brasília, Edição 95, Seção 1, p. 3, mai. 2018. Atos do Poder Executivo.

BRASIL. Decreto n. 9.983, de 22 de Agosto de 2019. Dispõe sobre a Estratégia Nacional de Disseminação do Building Information Modelling e institui o Comitê Gestor da Estratégia do Building Information Modelling. Diário Oficial da União, Brasília, Edição 163, Seção 1, p. 2, ago. 2019. Atos do Poder Executivo.

\section{CENTER FOR INTEGRATED FACILITY ENGINEERING. Virtual Design and Construction (VDC)}

Score. Stanford, 2013.

CHECCUCCI, E. Ensino-aprendizagem de BIM nos cursos de graduação em engenharia civil e o papel da expressão gráfica neste contexto. Salvador, 2014. Tese (Doutorado Multi-institucional e Multidisciplinar em Difusão do Conhecimento) - Universidade Federal da Bahia, Salvador, 2014.

CHECCUCCI, E. S. Teses e dissertações brasileiras sobre BIM: uma análise do período de 2013 a 2018. PARC Pesquisa em Arquitetura e Construção, Campinas, v. 10, fev. 2019.

CHEN, L.; LUO, H. A BIM-based construction quality management model and its applications. Automation in Construction, v. 46, p. 64-73, 2014.

CLEVENGER, C. M. et al. Integrating BIM Into Construction Management Education. In: THE BIMRELATED ACADEMIC WORKSHOP, Washington, 2010. Proceedingsn[...] Washington, 2010.

COMPUTER INTEGRATED CONSTRUCTION RESEARCH PROGRAM. BIM: project execution planning guide. Version 2.1. Pennsylvania: Penn State University, 2011.

CONSTRUCTION PROJECT INFORMATION COMMITTEE. CPIx - BIM Assessment Form. London, 2011.

GIEL, B.; ISSA, R. R. A. Quality and maturity of BIM implementation in the AECO Industry. Applied Mechanics and Materials, v. 438-439, p. 1621-1627, 2013.

GODOY, V.; CARDOSO, C.; BORGES, M. BIM: desafios para um conceito em construção no ensino de arquitetura e engenharia. In: CONGRESSO BRASILEIRO DE EDUCAÇÃO EM ENGENHARIA, 41., Gramado, 2013. Anais [...] Gramado: Cobenge, 2013.

GORDON, C.; AZAMBUJA, M.; WERNER, A. M. BIM Across the Construction Curriculum. In: ASC REGION III CONFERENCE, 3., Downers Grove, 2009. Proceeding [...] Downers Grove: Associated School of Construticion, 2009.

GU, N.; LONDON, K. Understanding and facilitating BIM adoption in the AEC industry.Automation in Construction, v.19, p. 988-999, dec. 2010.

HEVNER, A. R. A three cycle view of design science research. Scandinavian journal of information systems, v. 19, n. 2, p. 87-92, 2007.

HOLMSTRÖM, J.; KETOKIVI, M.; HAMERI, A. P. Bridging practice and theory: a design science approach. Decision Sciences, [S.l.], v. 40, n. 1, p. 65-87, 2009.

INDIANA UNIVERSITY. Indiana University BIM Standard. Indiana, 2009.

ITO, A. L. Y.; SCHEER, S. Um levantamento em Curitiba das percepções do potencial do BIM no ensino em cursos de arquitetura. In: SIMPÓSIO BRASILEIRO DE TECNOLOGIA DA INFORMAÇÃO E COMUNICAÇÃ̃ NA CONSTRUÇÃO, 1., Fortaleza, 2017. Anais [...] Fortaleza: Marketing Aumentado, 2017.

JERNIGAN, F. BIG Bim, Little Bim: the practical approach to building information modeling. Salisbury: 4Site Press, 2007. Practice Done the Right Way!

JUNG, Y.; JOO, M. Building information modelling (BIM) framework for practical implementation. Automation in Construction, v. 20, p. 126-133, 2011.

LEAL, B. M. F.; SALGADO, M. S. Propostas de incorporação de BIM no curso de Arquitetura e Urbanismo. PARC Pesquisa em Arquitetura e Construção, Campinas, v. 10, jul. 2019.

LIANG, C. et al. Development of a Multifunctional BIM Maturity Model. Journal of Construction

148 Böes, J. S.; Barros Neto, J. De P.; Lima, M. M. X. de 
Engineering and Management, v. 142, n. 11, p. 1-11, 2016.

LINO, J. C.; AZENHA, M.; LOURENÇO, P. Integração da metodologia BIM na engenharia de estruturas. In: ENCONTRO NACIONAL BETÃO ESTRUTURAL, Porto, 2012. Anais [...] Porto: FEUP, 2012.

LUKKA, K. The constructive research approach. In: OJALA, L.; HILMOLA, O-P. (ed.). Case study research in logistics. Turku: Turku School of Economics and Business Administration, 2003. Series B1.

MACHADO, F. A.; RUSCHEL, R. C.; SCHEER, S. Análise da produção científica brasileira sobre a Modelagem da Informação da Construção. Ambiente Construído, Porto Alegre, v. 17, n. 4, p. 359-384, out./dez. 2017.

NATIONAL INSTITUTE OF BUILDING SCIENCES. Facility Information Council (FIC): BIM Capability Maturity Model. Gaithersburg: National Institute of Standards and Technology, 2007.

PETERSON, F. et al. Teaching construction project management with BIM Support: experience and lessons learned. Automation in Construction, v. 20, n. 2, p. 115-125, 2011.

RODRIGUES, A. Grau de maturidade BIM: estudos de caso em empresas projetistas de Arquitetura na cidade de São Paulo. São Paulo, 2018. Monografia (Especialização em Gestão de Projetos de Construção) Universidade de São Paulo, São Paulo, 2018.

RUSCHEL, R. C.; ANDRADE, M. L. V. X.; MORAIS, M. O ensino de BIM no Brasil: onde estamos? Ambiente construído, Porto Alegre, v. 13, n. 2, p. 151-165, abr./jun. 2013.

SABONGI, F. The integration of BIM in the undergraduate curriculum: an analysis of undergraduate courses. In: ANNUAL CONFERENCE OF ASC, ASSOCIATED SCHOOL OF CONSTRUCTION, 45. Florida, 2009. Proceedings [...]Florida: Gainsville, 2009.

SACKS, R.; BARAK, R. Teaching Building Information Modeling as an integral part of freshman year Civil Engineering education. Journal of Professional Issues in Engineering Education and Practice. v. 136, n. 1, p. 30-38, jan. 2010.

SACKS, R.; PIKAS, E. Building information modeling education for construction engineering and management: I: industry requirements state of the art, and gap analisys. Journal of Construction Engineering and Management, v. 139, n. 11, nov. 2013.

SALGADO, M. S. Ensino de arquitetura, engenharia e tecnologias digitais: relato das experiências compartilhadas durante o ENEBIM. In: SIMPÓSIO BRASILEIRO DE TECNOLOGIA DA INFORMAÇÃO E COMUNICAÇÃO NA CONSTRUÇÃ̃O, 2., Campinas, 2019. Anais [...] Porto Alegre: ANTAC, 2019.

SEBASTIAN, R.; BERLO, L. V. Tool for benchmarking BIM performance of design, engineering and construction firms in the Netherlands. Architectural engineering and design management, v. 6, p. 254263, 2010.

SUCCAR, B. Building information modelling framework: a research and delivery foundation for industry stakeholders. Automation in construction, v. 18, p. 357-375, 2009.

SUCCAR, B. Building information modelling maturity matrix. In: UNDERWOOD, J.; ISIKDAG, U. (ed.). Handbook of research on building information modeling and construction informatics: concepts and technologies. Hershey: Information Science Reference, 2010.

SUCCAR, B.; KASSEM, M. Macro-BIM adoption: conceptual structures. Automation in Construction, v. 57, p. 64-79, 2015.

SUCCAR, B.; SALEEB, N.; SHER, W. Model uses: foundation for a modular requirements clarification language. In: AUSTRALASIAN UNIVERSITIES BUILDING EDUCATION, Australia, 2016. Proceedings [...] Australia: Cairns, 2016.

TSE, T. C. K.; WONG, K. D. A.; WONG, K. W. F. The utilization of building information models in nD modelling: a study of data interfacing and adoption barriers. Electronic Journal of Information Technology in Construction, v. 10, p. 85-110, 2005.

VAN AKEN, J. E. Management research based on the paradigma of the design sciences: the quest for fieldtested and grounded technological rules. Journal of Management Studies, v. 41, n. 2, p. 219-246, 2004. 
VICO. Calculating your BIM score. Software, 2011.

WONG, A. K. D.; WONG, F. K. W.; NADEEM, A. Comparative roles of major stakeholders for the implementation of BIM in various countries. In: INTERNATIONAL CONFERENCE ON CHANGING ROLES, Netherlands, 2009. Proceedings [...] Netherlands: The Hong Kong Polytechnic University, 2009.

WU, C. et al. Overview of BIM maturity measurement tools. Journal of Information Technology in Construction, v. 22, p. 34-62, 2017.

ZHOU, Y. et al. Formulating project-level building information modeling evaluation framework from the perspectives of organizations: a review. Automation in Construction, v. 81, p. 44-55, 2017.

\section{Acknowledgments}

To the Construction Industry Innovation Program (INOVACON) of Sinduscon Ceará, for the initiative and support in the development of this study.

\section{Jeferson Spiering Böes}

Departamento de Engenharia Civil | Faculdade Ari de Sá | Av. Heráclito Graça, 820, Centro | Fortaleza - CE - Brasil | CEP 60140-060 | Tel.: (85) 3077-9700 | E-mail: boes.jeferson@gmail.com

\section{José de Paula Barros Neto}

Departamento de Integração Acadêmica e Tecnológica | Universidade Federal do Ceará | Campus do Pici, Bloco 710, s/n | Fortaleza - CE Brasil | CEP 60020-181 | Tel.: (85) 3366-9600 | E-mail: barrosneto@gercon.ufc.br

\section{Mariana Monteiro Xavier de Lima}

Departamento de Arquitetura e Urbanismo e Design | Universidade Federal do Ceará | Av. da Universidade, 2890, Benfica | CEP 60020181 | Fortaleza - CE - Brasil | Tel.: (85) 33667490 | E-mail: mariana@daud.ufc.br

\section{Ambiente Construído}

Revista da Associação Nacional de Tecnologia do Ambiente Construído

Av. Osvaldo Aranha, $99-3^{\circ}$ andar, Centro

Porto Alegre - RS - Brasil

$$
\text { CEP } 90035-190
$$

Telefone: +55 (51) 3308-4084

Fax: +55 (51) 3308-4054

www.seer.ufrgs.br/ambienteconstruido

E-mail: ambienteconstruido@ufrgs.br 